\title{
COMPARISON OF FIVE ANTIOXIDANT ASSAYS FOR ESTIMATING ANTIOXIDANT CAPACITY FROM THREE SOLANUM SP. EXTRACTS
}

\author{
ATINA RIZKIYA CHOIRUNNISA, IRDA FIDRIANNY*, KOMAR RUSLAN \\ Pharmaceutical Biology Research Group, School of Pharmacy, Bandung Institute of Technology, Indonesia. \\ Email: irdafidrianny@gmail.com
}

Received: 30 May 2016, Revised and Accepted: 29 June 2016

\section{ABSTRACT}

Objectives: The aims of this research were to determine antioxidant capacity of various extracts from black nightshade, turkey berry, and round green eggplant using five antioxidant assays which were ferric reducing antioxidant power (FRAP), cupric reducing antioxidant capacity (CUPRAC), $\mathrm{H}_{2} \mathrm{O}_{2}$ scavenging, phosphomolybdenum assay, and beta-carotene bleaching (BCB), correlation of total phenolic, flavonoid, and carotenoid content with their inhibitory concentration $50 \%\left(\mathrm{IC}_{50}\right)$ and exhibitory concentration $50 \%\left(\mathrm{EC}_{50}\right)$ of five antioxidant assay and correlation between five antioxidant assays.

Methods: Extraction was conducted by reflux using gradient polarity solvents. The extracts were evaporated using rotary evaporator. The antioxidant capacity study, determination of phenolic, flavonoid, and carotenoid content were performed by ultraviolet-visible spectophotometry, while its correlation with $\mathrm{IC}_{50}$ and $\mathrm{EC}_{50}$ of five methods were analyzed by Pearson's method.

Results: Ethanolic and ethyl acetate fruit extracts of turkey berry denoted the highest antioxidant capacity using FRAP (EC ${ }_{50:} 41.32 \mu \mathrm{g} / \mathrm{ml}_{\text {) }}$ $\mathrm{H}_{2} \mathrm{O}_{2}$ scavenging assay $\left(\mathrm{IC}_{50:} 1.01 \mu \mathrm{g} / \mathrm{ml}\right)$, and CUPRAC $\left(\mathrm{EC}_{50} 117.56 \mu \mathrm{g} / \mathrm{ml}\right)$. While ethyl acetate fruit extract of round green eggplant gave the highest phosphomolybdenum capacity $\left(\mathrm{EC}_{50}: 375.47 \mu \mathrm{g} / \mathrm{ml}\right)$, and ethyl acetate fruit extract of black nightshade showed the highest $\mathrm{BCB}$ capacity $\left(\mathrm{EC}_{50} 158.66 \mu \mathrm{g} / \mathrm{ml}\right)$. Phenolic content of all fruit extracts had a tendency to correlate with FRAP and $\mathrm{H}_{2} \mathrm{O}_{2}$ scavenging antioxidant capacity, meanwhile flavonoid and carotenoid content had a tendency to correlate with CUPRAC, phosphomolybdenum, and BCB antioxidant capacity.

Conclusions: Phenolic compounds were a major contributor in antioxidant capacity of black nightshade, turkey berry, and round green eggplant extracts using FRAP and $\mathrm{H}_{2} \mathrm{O}_{2}$ scavenging, meanwhile flavonoid and carotenoid compounds were a major contributor in antioxidant capacity using CUPRAC, phosphomolybdenum and BCB assays. FRAP assay had linear correlation with $\mathrm{H}_{2} \mathrm{O}_{2}$ scavenging, meanwhile CUPRAC had linear correlation with phosphomolybdenum and BCB.

Keywords: Antioxidant, Antioxidant assays, Solanum fruits.

(C) 2016 The Authors. Published by Innovare Academic Sciences Pvt Ltd. This is an open access article under the CC BY license (http://creativecommons. org/licenses/by/4. 0/) DOI: http://dx.doi.org/10.22159/ajpcr.2016.v9s2.13155

\section{INTRODUCTION}

Reactive oxygen species (ROS) are produced as a normal product of metabolism [1]. Excess of ROS induces oxidative stress that contributing to degenerative diseases and aging $[1,2]$. Reactivity of ROS can be scavenged by antioxidant. There is evidence that consumption of fruits and vegetables effective to prevent negative effect of oxidative stress because they have phenolic, flavonoid, and carotenoid compound which have the antioxidant capacity [2]. Black nightshade (Solanum americanum Miller), turkey berry (Solanum torvum Swartz), and round green eggplant (Solanum coagulans Forsskal) are three local fruits from West Java that often used as traditional medicine and potentially have the antioxidant capacity [3-6].

There are some methods to determine antioxidant capacity in plant extracts; they are classified as the single electron transfer (SET), and hydrogen atom transferred (HAT)- based assays [7,8]. SET-based assay measures the capacity of antioxidant in the reduction of an oxidant, which color was changed when reduced. The degree of color change (either an increase or decrease of absorbance of the probe at a given wavelength) is correlated to the concentration of antioxidant in the sample [7]. Meanwhile, HAT-based assay measures the ability antioxidant to quench free radicals by hydrogen atom donation $[7,8]$.

The objectives of this research were to determine antioxidant capacity of nine plant extracts from black nightshade, turkey berry, and round green eggplant using five methods assay which were ferric reducing antioxidant power (FRAP), cupric reducing antioxidant capacity (CUPRAC), $\mathrm{H}_{2} \mathrm{O}_{2}$ scavenging, phosphomolybdenum assay, and betacarotene bleaching (BCB), correlation of total phenolic content (TPC), total flavonoid content (TFC), and total carotenoid content (TCC) with antioxidant capacity of five assays, and correlation between five antioxidant assays.

\section{METHODS}

\section{Materials}

Neocuproine (2,9-dimethyl-1,10-phenanthroline), 2,4,6-tripyridyls-triazine (TPTZ), linoleic acid, hydrogen peroxide, ammonium molybdate, sodium phosphate, sulfuric acid, ammonium acetate, sodium acetate, ferric chloride, copper (II) chloride, ascorbic acid, gallic acid, quercetin, beta-carotene, alpha-tocopherol were purchased from Sigma-Aldrich (MO, USA), black nightshade, turkey berry, and round green eggplant fruits. All other reagents were analytical grades.

\section{Preparation of sample}

Fruit from three Solanum sp. that were black nightshade (S. americanum Miller), namely, SA was collected from Pangalengan - West Java, turkey berry (S. torvum Swartz) as sample ST from Lembang - West Java, round green eggplant (S. coagulans Forsskal) as sample SC from Sumedang - West Java, were thoroughly washed with tap water, sorted while wet, cut, dried, and grinded into powder. 


\section{Extraction}

About $300 \mathrm{~g}$ of powdered samples were extracted by reflux using different polarity solvents. Extraction using n-hexane was repeated 3 times. The remaining residue was then extracted three times using ethyl acetate. Finally, the remaining residue was extracted three times using ethanol. Hence, totally there were nine extracts: three n-hexane extracts (SA1, ST1 AND SC1), three ethyl acetate extracts (SA2, ST2, and SC2), and three ethanolic extracts (SA3, ST3, and SC3).

\section{Exhibitory concentration $50 \%\left(\mathrm{EC}_{50}\right)$ of FRAP capacity}

Preparation of FRAP reagent was modified from Benzie's method [9] The FRAP reagent were prepared in acetate buffer $\mathrm{pH}$ 3.6. Various concentration of each extract was pipetted into FRAP $50 \mu \mathrm{g} / \mathrm{ml}$ (1:1) to initiate the reaction for obtaining a calibration curve. After 30 minutes incubation, the absorbance was observed at wavelength $593 \mathrm{~nm}$ using ultraviolet -visible (UV-Vis) spectrophotometer Beckman Coulter DU 720. Acetate buffer was used as a blank, FRAP $50 \mu \mathrm{g} / \mathrm{ml}$ as control and ascorbic acid as standard. The analysis was performed in triplicate for standard and each extract. Antioxidant capacity of each extract was determined based on increasing in Fe (II)-TPTZ absorbance by calculating the percentage of antioxidant capacity [9]. $\mathrm{EC}_{50}$ of FRAP capacity of each extract can be calculated using its calibration curve.

\section{$\mathrm{EC}_{50}$ of CUPRAC}

Preparation of CUPRAC reagent was conducted using the method from Apak et al. [10] with minor modification. The CUPRAC reagent was prepared in ammonium acetate buffer $\mathrm{pH}$ 7. The various concentration of each extract was pipetted into CUPRAC $50 \mu \mathrm{g} / \mathrm{ml}(1: 1)$ to initiate the reaction for obtaining a calibration curve. After 30 minutes incubation, the absorbance was read at wavelength $450 \mathrm{~nm}$ using UV- Vis spectrophotometer Beckman Coulter DU 720. Ammonium acetate buffer was used as a blank, CUPRAC $50 \mu \mathrm{g} / \mathrm{ml}$ as control and ascorbic acid as standard. The analysis was done in triplicate for standard and each extract. Antioxidant capacity of each extract was determined based on increasing in $\mathrm{Cu}$ (I)-neocuproine absorbance by calculating the percentage of antioxidant capacity [10]. $\mathrm{EC}_{50}$ of CUPRAC capacity of each extract can be calculated using its calibration curve.

\section{Inhibitory concentration $50 \%\left(\mathrm{IC}_{50}\right)$ of $\mathrm{H}_{2} \mathrm{O}_{2}$ scavenging assay}

Preparation of $\mathrm{H}_{2} \mathrm{O}_{2}$ solution was adopted from Ruch et al. [11]. $\mathrm{H}_{2} \mathrm{O}_{2}$ solution was prepared in phosphate buffer $\mathrm{pH}$ 7.4. The various concentration of each extract was pipetted into $\mathrm{H}_{2} \mathrm{O}_{2} 68 \mu \mathrm{g} / \mathrm{ml}$ (1:1) to initiate the reaction for obtaining a calibration curve. After 10 minutes incubation, the absorbance was read at wavelength $230 \mathrm{~nm}$ using UVVis spectrophotometer Beckman Coulter DU 720. Phosphate buffer was used as a blank, $\mathrm{H}_{2} \mathrm{O}_{2} 68 \mu \mathrm{g} / \mathrm{ml}$ as control and ascorbic acid as standard. Analysis was carried out in triplicate for standard and each extract. Antioxidant capacity of each extract was determined based on ability to decrease absorbance of $\mathrm{H}_{2} \mathrm{O}_{2}$ [11]. $\mathrm{IC}_{50}$ of $\mathrm{H}_{2} \mathrm{O}_{2}$ scavenging of each extract can be calculated using its calibration curve.

\section{$\mathrm{EC}_{50}$ of phosphomolybdenum assay}

Preparation of phosphomolybdenum reagent was performed using modified Prieto's method [12]. The various concentration of each extract was pipetted into phosphomolybdenum reagent $50 \mu \mathrm{g} / \mathrm{ml}$ (1:1) to initiate the reaction for obtaining a calibration curve. The tubes were capped and incubated in water bath at $95^{\circ} \mathrm{C}$ for 90 minutes. Left the samples cooled, then absorbance was measured at wavelength $695 \mathrm{~nm}$ using UV-Vis spectrophotometer Beckman Coulter DU 720. Distilled water was used as a blank, phosphomolybdenum $50 \mu \mathrm{g} / \mathrm{ml}$ as control and alpha-tocopherol as standard. Analysis was conducted in triplicate for standard and each extract. Antioxidant capacity of each extract was determined based on increasing absorbance of Mo (V)-phosphate [12] $\mathrm{EC}_{50}$ phosphomolybdenum capacity of each extract can be calculated using its calibration curve.

\section{$\mathrm{EC}_{50}$ of BCB assay}

Preparation of BCB reagent was performed using the method from Othman et al. [13] and Marco [14], with minor modification. The various concentration of each extract was pipetted into beta-carotenelinoleic acid emulsion $100 \mu \mathrm{g} / \mathrm{ml}$ (1:1) to initiate the reaction for obtaining a calibration curve. The tubes were capped and incubated in water bath at $50^{\circ} \mathrm{C}$ for 120 minutes. After the samples cooled, the absorbance was observed at wavelength $470 \mathrm{~nm}$ against a blank using UV-Vis spectrophotometer Beckman Coulter DU 720. Emulsion without beta-carotene was used as a blank, beta-carotene-linoleic acid emulsion $100 \mu \mathrm{g} / \mathrm{ml}$ as control and ascorbic acid as standard. Analysis was done in triplicate for standard and each extract. Antioxidant capacity of each extract was determined based on ability antioxidant in minimizing beta carotene oxidation [14]. $\mathrm{EC}_{50} \mathrm{BCB}$ of each extract can be calculated using its calibration curve.

\section{TFC, TPC, and TCC}

TFC was measured using modified method from Chang et al. [15]. The absorbance was read at wavelength $415 \mathrm{~nm}$. Analysis was done in triplicate for each extract. The TFC was exposed as a percentage of total quercetin equivalent per $100 \mathrm{~g}$ extract (g QE/100 g). Determination of TPC was adapted from Pourmorad et al. [16] using Folin-Ciocalteu reagent. The absorbance was measured at wavelength $765 \mathrm{~nm}$. TPC was reported as a percentage of total gallic acid equivalent per $100 \mathrm{~g}$ extract ( $\mathrm{g} \mathrm{GAE} / 100 \mathrm{~g}$ ). Evaluation of TCC was performed using the method from Thaipong et al. [17] with minor modification. Each extract was diluted in acetone. The absorbance was read at wavelength $470 \mathrm{~nm}$. The TCC was demonstrated as a percentage of total beta-carotene equivalent per $100 \mathrm{~g}$ extract (g BE/100 g).

\section{Statistical analysis}

Each sample analysis was performed in triplicate. All of the presented results are means ( \pm standard deviation) of at least three independent experiments. Statistical analysis using analysis of variance with a statistical significance level set at $\mathrm{p}<0.05$ and post-hoc Tukey procedure was carried out with SPSS 16 for windows. Correlation between the TPC, TFC, TCC, and antioxidant capacity, and the correlation between five antioxidant capacity methods were carried out using the Pearson's method.

\section{RESULTS}

Antioxidant capacity of fruit extracts of Solanum sp. using five methods

Antioxidant capacity in various fruit extracts of Solanum sp. using five methods were shown in Figs. 1-5. $\mathrm{IC}_{50}$ and $\mathrm{EC}_{50}$ of each extract were compared to ascorbic acid, quercetin, and alpha-tocopherol as standard. The lowest value of $\mathrm{IC}_{50}$ and $\mathrm{EC}_{50}$ means had the highest antioxidant activity.

\section{TFC, TPC, and TCC in various fruit extracts of Solanum sp.}

The TFC in various fruit extracts from black nightshade, turkey berry, and round green eggplant had a different results varied from 0.44 to

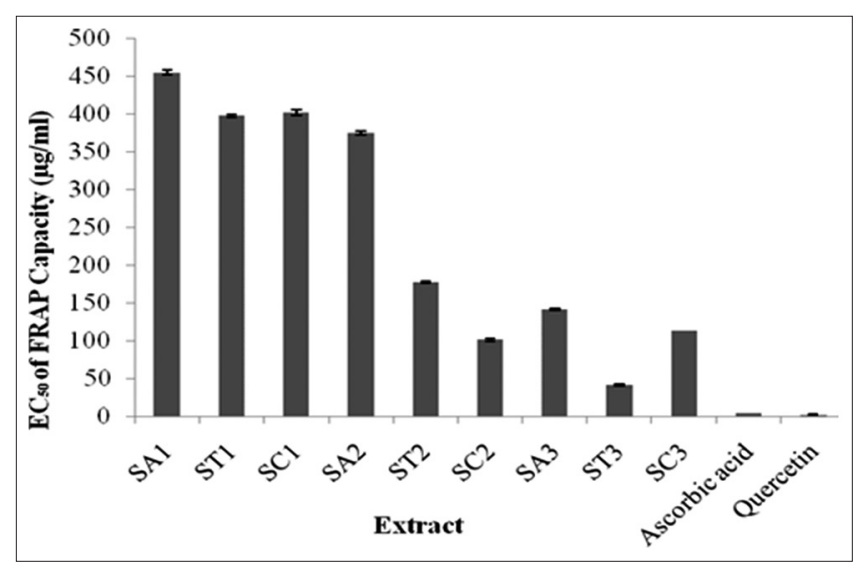

Fig. 1: Exhibitory concentration $50 \%$ of ferric reducing antioxidant power of Solanum fruit extracts, $n=3$ 


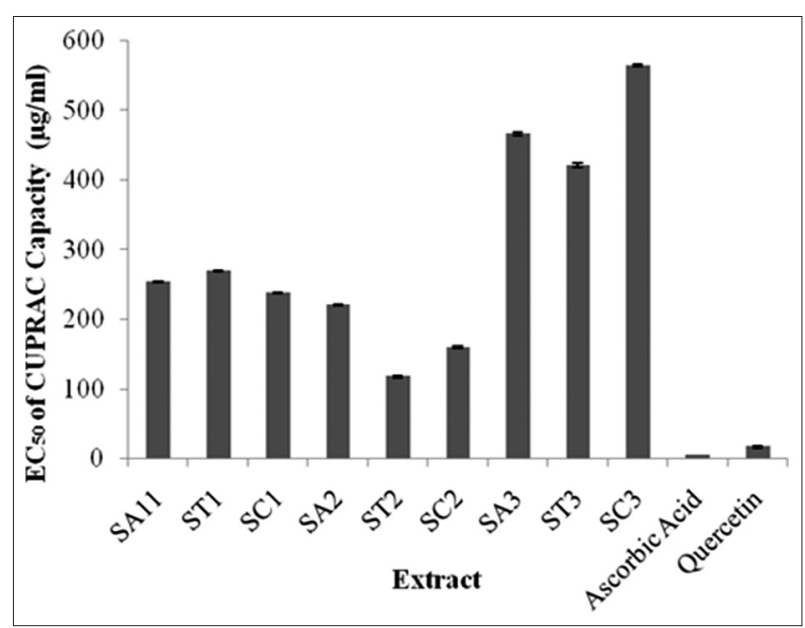

Fig. 2: Exhibitory concentration $50 \%$ of cupric reducing antioxidant capacity of Solanum fruit extracts, $n=3$

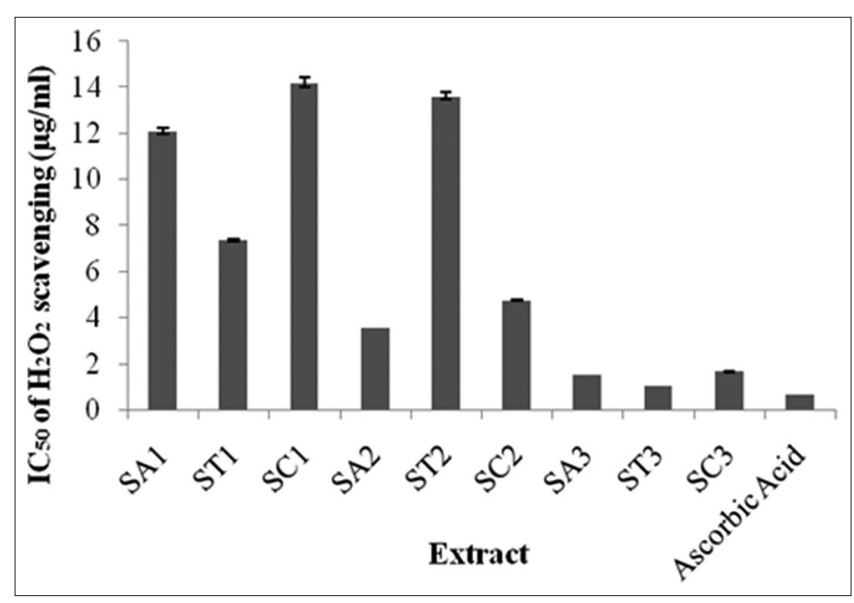

Fig. 3: Inhibitory concentration $50 \%$ of $\mathrm{H}_{2} \mathrm{O}_{2}$ scavenging of Solanum fruit extracts, $\mathrm{n}=3$

9.37 g QE/100 g, TPC in the range of 0.30-5.15 g GAE/100 $\mathrm{g}$ and TCC ranged from 0.0088 to $0.87 \mathrm{~g} \mathrm{BE} / 100 \mathrm{~g}$ (Table 1). Ethyl acetate extract of black nightshade (SA2) showed the highest TFC (9.37 g QE/100 g) and the highest TCC $(0.87 \mathrm{~g} \mathrm{BE} / 100 \mathrm{~g})$. The highest phenolic content (5.15 g GAE/100 g) was given by ethanolic extract of turkey berry (ST3).

\section{DISCUSSION}

Black nightshade (SA Miller), turkey berry (ST Swartz), and round green eggplant (SC Forsskal) are three local fruits from West Java, Indonesia that often used as traditional medicine [3-6]. Several studies revealed that fruit of black nightshade, turkey berry, and round green eggplant had antioxidant capacity. Antioxidant capacity of Solanum nigrum and ST using 2,2-diphenyl-1-picrylhydrazyl, 2,2'-azino-bis(3ethylbenzothiazoline-6-sulfonic acid), and FRAP assays had been studied [18-21], meanwhile Somawathi et al. [22] compared the antioxidant activity from different skin colored eggplant (Solanum melongena). There was no research that comparing antioxidant capacity of various fruit extracts of SA Miller, ST Swartz, and SC Forsskal using five methods which were FRAP, CUPRAC, $\mathrm{H}_{2} \mathrm{O}_{2}$ scavenging, phosphomolybdenum assay, and BCB.

Basic classification of in vitro antioxidant capacity is based on type of reaction, which are SET-based assay and HAT-based assay [7]. SET assay is based on the ability of antioxidant to transfer one electron to reduce oxidant [8]. The degree of color change (either increase or decrease of absorbance of the probe at a given wavelength) is

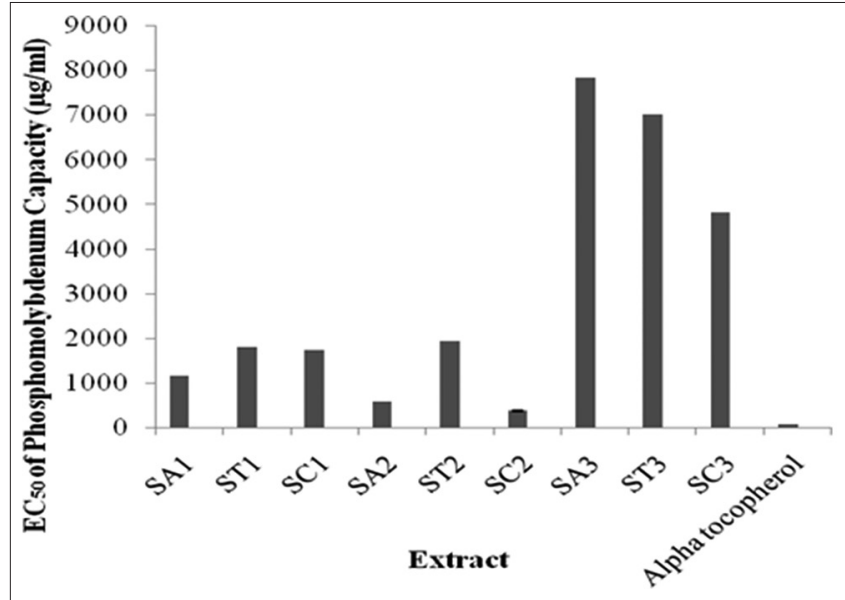

Fig. 4: Exhibitory concentration $50 \%$ of phosphomolybdenum capacity of Solanum fruit extracts, $n=3$

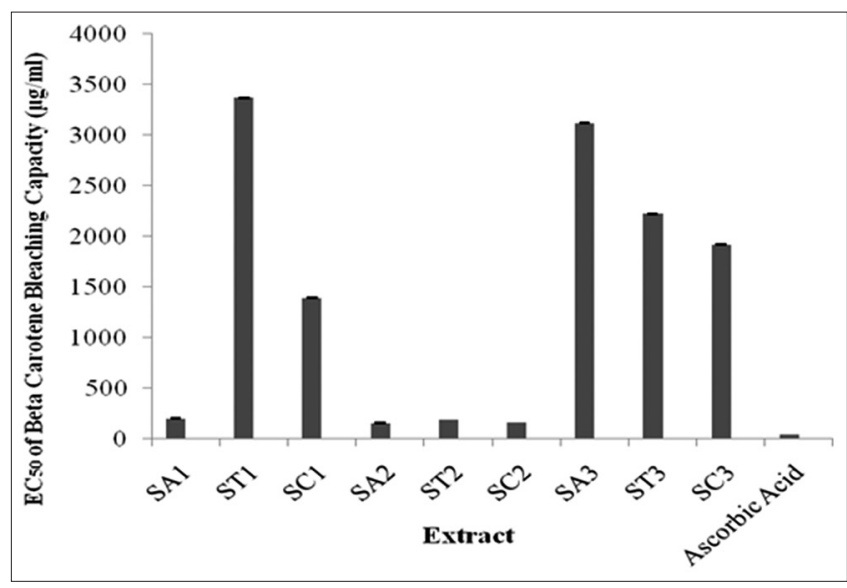

Fig. 5: Exhibitory concentration $50 \%$ of beta-carotene bleaching capacity of Solanum fruit extracts, $n=3$

Table 1: TFC, TPC, and TCC of Solanum fruit extracts

\begin{tabular}{llll}
\hline Sample & $\begin{array}{l}\text { TFC } \\
\text { (g QE/100 g) }\end{array}$ & $\begin{array}{l}\text { TPC } \\
\text { (g GAE/100 g) }\end{array}$ & $\begin{array}{l}\text { TCC } \\
\text { (g BE/100 g) }\end{array}$ \\
\hline SA1 & $2.25 \pm 0.29^{\mathrm{a}}$ & $0.30 \pm 0.008^{\mathrm{a}}$ & $0.45 \pm 0.009^{\mathrm{a}}$ \\
ST1 & $1.21 \pm 0.12^{\mathrm{a}}$ & $0.84 \pm 0.15^{\mathrm{b}}$ & $0.46 \pm 0.05^{\mathrm{a}}$ \\
SC1 & $2.57 \pm 0.42^{\mathrm{b}}$ & $0.60 \pm 0.02^{\mathrm{b}}$ & $0.087 \pm 0.017^{\mathrm{b}}$ \\
SA2 & $9.37 \pm 0.47^{\mathrm{a}}$ & $2.85 \pm 0.11^{\mathrm{a}}$ & $0.87 \pm 0.03^{\mathrm{a}}$ \\
ST2 & $6.34 \pm 0.29^{\mathrm{b}}$ & $3.23 \pm 0.34^{\mathrm{a}}$ & $0.16 \pm 0.001^{\mathrm{b}}$ \\
SC2 & $5.45 \pm 0.39^{\mathrm{c}}$ & $2.62 \pm 0.06^{\mathrm{a}}$ & $0.12 \pm 0.0009^{\mathrm{b}}$ \\
SA3 & $1.13 \pm 0.08^{\mathrm{a}}$ & $3.08 \pm 0.43^{\mathrm{a}}$ & $0.02 \pm 0.002^{\mathrm{a}}$ \\
ST3 & $0.58 \pm 0.02^{\mathrm{b}}$ & $5.15 \pm 0.96^{\mathrm{b}}$ & $0.0098 \pm 0.0002^{\mathrm{b}}$ \\
SC3 & $0.44 \pm 0.03^{\mathrm{c}}$ & $4.34 \pm 0.11^{\mathrm{b}}$ & $0.0088 \pm 0.0004^{\mathrm{b}}$ \\
\hline
\end{tabular}

SA: black nightshade, ST: turkey berry, SC: round green eggplant, 1: n-hexane extract, 2: ethyl acetate extract, 3: Ethanolic extract, $n=3$. Different letter in one cell showed a significant difference at $\mathrm{p}<0.05$. TPC: Total phenolic content, TFC: Total flavonoid content, TCC: total carotenoid content, QE: Quercetin equivalent, GAE: gallic acid equivalent, BE: beta-carotene equivalent

correlated to the concentration of antioxidant in the sample [7]. Meanwhile, HAT-based assay measure ability of antioxidant to quench radical by hydrogen donation [8]. SET and HAT mechanism almost always occur together, and mechanism that appear predominantly is influenced by ionization potential (DIP), bond dissociation energy (BDE), redox potential, $\mathrm{pH}$, and solvent $[7,8]$. Antioxidant mechanism is predominantly SET for compound with $\triangle \mathrm{IP}>-45 \mathrm{kcal} / \mathrm{mol}$, and predominantly HAT for compound with DBDE of $\sim 10 \mathrm{kcal} / \mathrm{mol}$ and $\Delta \mathrm{IP}<-36 \mathrm{kcal} / \mathrm{mol}[8]$. 
FRAP measure reduction of $\mathrm{Fe}^{3+}$-TPTZ to $\mathrm{Fe}^{2+}$-TPTZ by antioxidant at low $\mathrm{pH}$, form an intense blue color with maximum absorbance at $593 \mathrm{~nm}$ [9]. This method is fast, reproducible, and non-specific [9]. Any compound which has lower reduction potential than $0.77 \mathrm{~V}$ (redox potential of $\mathrm{Fe}^{3+} / \mathrm{Fe}^{2+}$ ) can be detected by FRAP assay $[9,23]$. EC of FRAP capacity is a concentration of sample or standard that can exhibit $50 \%$ of FRAP capacity. The lowest $\mathrm{EC}_{50}$ means had the highest antioxidant capacity. $\mathrm{EC}_{50}$ were used to determine antioxidant capacity of sample was compared to standard [24].

CUPRAC assay is based on reduction $\mathrm{Cu}^{2+}$ to $\mathrm{Cu}^{+}$by antioxidant at $\mathrm{pH} \mathrm{7}$, and $\mathrm{Cu}^{+}$react with neocuproine form $\mathrm{Cu}^{+}$-neocuproine, yielding a chromophore with maximum absorbance at $490 \mathrm{~nm}[8,10]$. CUPRAC assay is fast, stable, and selective. It has lower reduction potential $(0.159 \mathrm{~V})$ than FRAP reagent, so that simple sugar and citric acid are not detected [10].

Hydrogen peroxide can be formed in vivo by metabolism process. It can cross cell membrane and attack many cellular compound. Hydrogen peroxide reacts with $\mathrm{Fe}$ to produce free radicals [25]. $\mathrm{H}_{2} \mathrm{O}_{2}$ scavenging assay measure ability of antioxidant to scavenge hydrogen peroxide in $\mathrm{pH} 7.4$ [11] $\mathrm{H}_{2} \mathrm{O}_{2}$ solutions have high redox potential $(1.776 \mathrm{~V})$, hence any compound with lower reduction potential than $\mathrm{H}_{2} \mathrm{O}_{2}$ can be detected [26].

Molybdenum is active side of xanthine oxidase, an enzyme that produces free radicals [27]. Phosphomolybdenum assay measure reduction of Mo (VI) to Mo (V) and subsequent formation of a green phosphate-Mo (V) complex at acidic $\mathrm{pH}$ [12]. The reaction of Mo (VI) to Mo (V) has reduction potential $0.43 \mathrm{~V}$.

BCB is one of HAT-based assays. This method measure ability of antioxidant to minimize beta-carotene oxidation in linoleic acid emulsion system [28]. Linoleic acid produces hydroperoxide radicals during incubation at $50^{\circ} \mathrm{C}$. These radicals oxidize beta-carotene and generate decolorization of it. The presence of antioxidant will minimize the oxidation of beta-carotene by donating hydrogen atom to radical [28].

The $\mathrm{EC}_{50}$ of various fruit extracts of black nightshade, turkey berry, and round green eggplant were shown in Figs. 1-5. In this study, exposed that $\mathrm{EC}_{50}$ FRAP of various extracts varied from 41.32 to $454.36 \mu \mathrm{g} / \mathrm{ml}$, $\mathrm{EC}_{50}$ CUPRAC 117.56 to $564.34 \mu \mathrm{g} / \mathrm{ml}, \quad \mathrm{IC}_{50} \quad \mathrm{H}_{2} \mathrm{O}_{2}$ scavenging $1.01-14.2 \mu \mathrm{g} / \mathrm{ml}$. Meanwhile, $\mathrm{EC}_{50}$ phosphomolybdenum assay in the range of $375.47-7833.19 \mu \mathrm{g} / \mathrm{ml}$, and $\mathrm{EC}_{50}$ of $\mathrm{BCB} 158.66-3370 \mu \mathrm{g} / \mathrm{ml}$.
The present study revealed that ethanolic extract of turkey berry had the highest antioxidant capacity using FRAP and $\mathrm{H}_{2} \mathrm{O}_{2}$ scavenging assay, meanwhile ethyl acetate extract of turkey berry had the highest antioxidant capacity using CUPRAC assay. Ethyl acetate of round green eggplant had the highest phosphomolybdenum antioxidant capacity, and ethyl acetate extract of black nightshade had the highest antioxidant capacity using BCB assay.

Quercetin has firstredox potential $-0.11 \mathrm{~V}$, lower than reduction potential of CUPRAC reagent and FRAP reagent [29]. Therefore, quercetin showed good antioxidant capacity using CUPRAC and FRAP assay.

Copper, free, and in phenanthroline complex has low reduction potential. This low reduction potential enhances redox cycling, a repeat redox reaction [8]. Therefore, a high concentration of extract is required to reduce $\mathrm{Cu}^{2}$ to $\mathrm{Cu}^{+}$and make higher $\mathrm{EC}_{50}$ value.

Hydrogen peroxide has redox potential $1.776 \mathrm{~V}$ [26]. Any compound with lower reduction potential than $1.776 \mathrm{~V}$ can be detected using $\mathrm{H}_{2} \mathrm{O}_{2}$ scavenging assay. Several studies revealed that flavonoid phenolic, and carotenoid compound has lower reduction potential than hydrogen peroxide [30-32]. Therefore, in the present study, all extract showed high antioxidant capacity (low $\mathrm{IC}_{50}$ ) because there were many compounds could scavenge hydrogen peroxide.

There are two steps in phosphomolybdenum complex formation. The first step is formation of 12-molybdophosphoric acid (12-MPA) (Mo VI), and the next step is a reduction of 12-MPA to phosphomolybdenum complex (Mo V) by antioxidant. The stoichiometric of Mo (VI) and 12- MPA is $6: 1$ [33]. In the present study which was adopted from Prieto et al. [12], the amount of ammonium molybdate which was used too low, so that only a little 12-MPA formed and then react with antioxidant and gave phosphomolybdenum complex. It might be still many excessive antioxidant in sample will oxidize again Mo (V) to Mo (VI). These reactions will be repeated in many times between Mo (VI) to Mo (V) and Mo (V) to Mo (VI); therefore, it denoted that the extract had higher $\mathrm{EC}_{50}$ phosphomolydenum capacity.

Antioxidant capacity using BCB assay is correlated to solubility, antioxidant structure, and chemical bond. The presence of hydrogen bonding between phenolic and emulgator Tween 20 will decrease antioxidant capacity of phenolic acid [34]. This study corresponding to result of the present study, where phenolic was not correlated with antioxidant capacity using BCB assay.

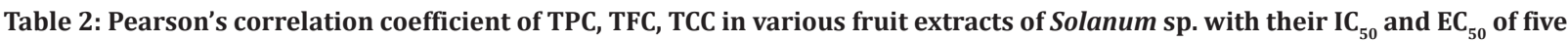
antioxidant assays

\begin{tabular}{|c|c|c|c|c|c|c|c|}
\hline \multirow[t]{2}{*}{ Antioxidant parameter } & \multicolumn{7}{|c|}{ Coefficient correlation Pearson (r) } \\
\hline & $\begin{array}{l}\text { Total } \\
\text { phenolic }\end{array}$ & $\begin{array}{l}\text { Total } \\
\text { flavonoid }\end{array}$ & $\begin{array}{l}\text { Total } \\
\text { carotenoid }\end{array}$ & EC $_{50}$ FRAP & $\mathrm{EC}_{50}$ CUPRAC & $\mathrm{IC}_{50} \mathrm{H}_{2} \mathrm{O}_{2}$ & $\mathrm{EC}_{50} \mathrm{BCB}$ \\
\hline $\mathrm{EC}_{50}$ FRAP (SA) & $-0.850^{* *}$ & $0.203^{\text {ns }}$ & $0.574^{\mathrm{ns}}$ & & & & \\
\hline $\mathrm{EC}_{50}^{30}$ FRAP (ST) & $-0.959^{* *}$ & $-0.050^{\mathrm{ns}}$ & $0.992^{* *}$ & & & & \\
\hline $\mathrm{EC}_{50}^{\mathrm{J0}}$ FRAP (SC) & $-0.870^{* *}$ & $-0.122^{\text {ns }}$ & $0.211^{\mathrm{ns}}$ & & & & \\
\hline $\mathrm{EC}_{50}$ CUPRAC (SA) & $0.452^{\mathrm{ns}}$ & $-0.696^{*}$ & $-0.924 * *$ & $-0.843^{* *}$ & & & \\
\hline $\mathrm{EC}_{50}^{50}$ CUPRAC (SC) & $0.730^{*}$ & $-0.903^{* *}$ & $-0.981^{* *}$ & $-0.300^{\mathrm{ns}}$ & & & \\
\hline $\mathrm{IC}_{50} \mathrm{H}_{2} \mathrm{O}_{2}$ scavenging (SA) & $-0.980^{* *}$ & $-0.214^{\mathrm{ns}}$ & $0.189^{\text {ns }}$ & $0.912 * *$ & $-0.549^{\mathrm{ns}}$ & & \\
\hline $\mathrm{IC}_{50}^{50} \mathrm{H}_{2}^{2} \mathrm{O}_{2}^{2}$ scavenging (ST) & $-0.446^{\mathrm{ns}}$ & $0.902^{* *}$ & $0.343^{\text {ns }}$ & $0.384^{\mathrm{ns}}$ & $-1.00^{* *}$ & & \\
\hline $\mathrm{IC}_{50} \mathrm{H}_{2} \mathrm{O}_{2}$ scavenging (SC) & $-0.970^{* *}$ & $0.151^{\mathrm{ns}}$ & $0.466^{\mathrm{ns}}$ & $0.962^{* *}$ & $-0.546^{\mathrm{ns}}$ & & \\
\hline $\mathrm{EC}_{50} \mathrm{BCB}(\mathrm{SA})$ & $0.544^{\mathrm{ns}}$ & $-0.613^{*}$ & $-0.876^{* *}$ & $-0.898^{* *}$ & $0.994^{* *}$ & $-0.638^{*}$ & \\
\hline $\mathrm{EC}_{50}^{50} \mathrm{BCB}(\mathrm{ST})$ & $-0.397^{\mathrm{ns}}$ & $-0.893^{* *}$ & $0.522^{\text {ns }}$ & $0.490^{\mathrm{ns}}$ & $0.633^{*}$ & $-0.616^{*}$ & \\
\hline $\mathrm{EC}_{50}^{\mathrm{So}} \mathrm{BCB}(\mathrm{SC})$ & $0.248^{\text {ns }}$ & $-0.981^{* *}$ & $-0.872^{* *}$ & $0.262^{\mathrm{ns}}$ & $0.842^{* *}$ & $-0.008^{\mathrm{ns}}$ & \\
\hline $\mathrm{EC}_{50}^{50}$ phosphomolibdenum (SA) & $0.496^{\mathrm{ns}}$ & $-0.658^{*}$ & $-0.902^{* *}$ & $-0.870^{* *}$ & $0.999 * *$ & $0.592^{\text {ns }}$ & $0.998^{* *}$ \\
\hline $\mathrm{EC}_{50}^{50}$ phosphomolibdenum (SC) & $0.643^{*}$ & $-0.945^{* *}$ & $-0.984^{* *}$ & $-0.183^{\text {ns }}$ & $0.993^{* *}$ & $-0.441^{\mathrm{ns}}$ & $0.901^{* *}$ \\
\hline
\end{tabular}

SA: Black nightshade, ST: Turkey berry, SC: Round green eggplant, ns: Not significant, *Significant at p<0.05, **Significant at p<0.01. CUPRAC: Cupric reducing antioxidant capacity, FRAP: Ferric reducing antioxidant power, BCB: Beta-carotene bleaching 
Phenolic, flavonoid, and carotenoid might have antioxidant capacity [24]. Based on Pearson correlation on Table 2, phenolic content of all sample fruit extracts had a tendency to correlate with FRAP and $\mathrm{H}_{2} \mathrm{O}_{2}$ scavenging assay. Antioxidant capacity using FRAP appears to be related to the degree of hydroxylation and extent of conjugation in polyphenols [8]. Meanwhile, antioxidant capacity using $\mathrm{H}_{2} \mathrm{O}_{2}$ scavenging assay is related to number and position of hydroxyl group bonded to the aromatic ring. Ortho and para hydroxyl substitution have stronger antioxidant capacity [35]. Therefore, it can be predicted that major phenolic compounds in all sample fruit extracts have higher degree of hydroxylation and extent of conjugation, but only black nightshade and round green eggplant extracts have phenolic with ortho and/or para hydroxyl substitution.

Flavonoid and carotenoid content of all sample fruit extracts had a tendency to correlate with CUPRAC, phosphomolybdenum, and BCB assay. Flavonoid may have antioxidant effect as hydrogen-donating compound, metal chelating ion, single oxygen transfer, and singlet oxygen quencher [36]. Basically, structural requirement for hydrogen donating and metal chelating is related to o-dihydroxy structure in the ring $\mathrm{B}, \mathrm{C}-2-\mathrm{C}-3$ double bond and oxo group at $\mathrm{C}-4$ [36]. The presence of $\mathrm{OH}$ at $\mathrm{C}-3$ and $\mathrm{C}-5$ will increase metal chelating activity of flavonoid. Therefore, it can be predicted that major flavonoid compounds in all sample have o-dihydroxy, C-2-C-3 double bond and oxo group at C-4.

Carotenoid a compound that contributes to yellow color of fruits and vegetables have antioxidant capacity. The structural requirement for antioxidant capacity of carotenoid is the presence of conjugated double bonds. Carotenoids that contain more than seven conjugated double bonds were reported to have stronger antioxidant capacity [37].

This study showed that a single in vitro antioxidant method was not possible to determine antioxidant capacity of extract. Each method had different mechanism and the result might be different. Therefore, it was important that variety of assays with different mechanism was used on plant extract to investigate its antioxidant potential.

\section{CONCLUSION}

Antioxidant activity of sample should be measured using different assay in parallel because different method gave a different result. Turkey berry extract showed good antioxidant capacity using FRAP, $\mathrm{H}_{2} \mathrm{O}_{2}$ scavenging assay, and CUPRAC method and potential to be developed as source of natural antioxidant. Phenolic compounds were major contributor in antioxidant capacity of black nightshade, turkey berry, and round green eggplant extracts using FRAP and $\mathrm{H}_{2} \mathrm{O}_{2}$ scavenging assays, meanwhile flavonoid and carotenoid compounds were major contributor in antioxidant capacity using CUPRAC, phosphomolybdenum, and $\mathrm{BCB}$ assays.

\section{REFERENCES}

1. Sharma P, Jha AB, Dubey RS, Pessarakli M. Reactive oxygen species, oxidative damage, and antioxidative defense mechanism in plants under stressful conditions. J Bot 2012;2012:1-26.

2. Gramza-Michalowska A, Czlapka-Matyasik M. Evaluation of the antiradical potential of fruit and vegetable snacks. Acta Sci Pol Technol Aliment 2011;10(1):63-72.

3. Rajani C, Ruby KM, Aastha S, Jaya D. Solanum nigrum with dinamic therapeutic rule: A review. Int J Pharm Sci Rev Res 2012;15(1):65-71.

4. Chah KF, Muko KN, Oboegbulem SI. Antimicrobial activity of methanolic extract of Solanum torvum fruit. Fitoterapia 2000;71(2):187-9.

5. Mohan M, Jaiswal BS, Kasture S. Effect of Solanum torvum on blood pressure and metabolic alterations in fructose hypertensive rats. J Ethnopharmacol 2009;126(1):86-9.

6. Mutalik S, Paridhavi K, Rao CM, Udupa N. Antipyretic and analgesic effect of leaves of Solanum melongena Linn. in rodents. Indian J Pharmacol 2003;35:312-5.

7. Apak R, Gorinstein S, Böhm VK, Schaich MK. Methods of measurement and evaluation of natural antioxidant capacity activity:
IUPAC technical report. Pure Appl Chem 2013;85(5):957-98.

8. Prior RL, Wu X, Schaich K. Standardized methods for the determination of antioxidant capacity and phenolics in foods and dietary supplements. J Agric Food Chem 2005;53(10):4290-302.

9. Benzie IF, Strain JJ. The ferric reducing ability of plasma (FRAP) as a measure of "antioxidant power": The FRAP assay. Anal Biochem 1996;239(1):70-6.

10. Apak R, Gü̧̈lü K, Ozyürek M, Karademir SE. Novel total antioxidant capacity index for dietary polyphenols and vitamins $\mathrm{C}$ and $\mathrm{E}$, using their cupric ion reducing capability in the presence of neocuproine: CUPRAC method. J Agric Food Chem 2004;52(26):7970-81.

11. Ruch RJ, Cheng SJ, Klaunig JE. Prevention of cytotoxicity and inhibition of intercellular communication by antioxidant catechins isolated from Chinese green tea. Carcinogenesis 1989;10(6):1003-8.

12. Prieto P, Pineda M, Aguilar M. Spectrophotometric quantitation of antioxidant capacity through the formation of a phosphomolybdenum complex: Specific application to the determination of vitamin E. Anal Biochem 1999;269(2):337-41

13. Othman A, Ismail A, Ghani NA, Adenan I. Antioxidant capacity and phenolic content of cocoa beans. Food Chem 2007;100(4):1523-30.

14. Marco GJ. A rapid method for evaluation of antioxidants. J Am Chem Oil Soc 1968;45:594-8.

15. Chang CC, Yang MH, Wen HM, Chern JC. Estimation of total flavonoid content in propolis by two complementary colorimetric methods. J Food Drug Anal 2002;10(3):178-82.

16. Pourmorad F, Hosseinimehr SJ, Shahabimajd N. Antioxidant activity, phenol and flavonoid content of some selected Iranian medicinal plants. Afr J Biotechnol 2006;5(11):1142-5.

17. Thaipong K, Unaroj B, Kevin C, Luis CZ, David HB. Comparison of ABTS, DPPH, FRAP and ORAC assays for estimating antioxidant activity from guajava fruit extracts. J Food Compost Anal 2006;19:670-1.

18. Loganayaki N, Siddhuraju P, Manian S. Antioxidant activity of two traditional Indian vegetables: Solanum nigrum L. And Solanum torvum L. Food Sci Biotechnol 2010;19(1):121-7.

19. Al-Fatimi M, Wurster M, Schröder G, Lindequist U. Antioxidant, antimicrobial and cytotoxic activities of selected medicinal plants from Yemen. J Ethnopharmacol 2007;111(3):657-66.

20. Ramamurthy $\mathrm{CH}$, Kumar MS, Suyavaran VS, Mareeswaran R, Thirunavukkarasu C. Evaluation of antioxidant, radical scavenging activity and polyphenolics profile in Solanum torvum L. Fruits. J Food Sci 2012;77(8):C907-13.

21. Adebooye OC, Vijayalakshmi R, Singh V. Peroxidase activity, chlorophylls and antioxidant profile of two leaf vegetables (Solanum nigrum L. and Amaranthus cruentus L.) under six pretreatment methods before cooking. Int J Food Sci Technol 2008;43(1):173-8.

22. Somawathi KM, Rizliya V, Wijesinghe DG, Madhujith WM. Antioxidant activity and total phenolic content of different skin coloured brinjal (Solanum melongena). Trop Agric Res 2014;26(1):152-61.

23. MacDonald-Wicks LK, Wood LG, Garg ML. Methodology for the determination of biological antioxidant capacity in vitro: A review. J Sci Food Agric 2006;86:2046-56.

24. Fidrianny I, Johan Y, Sukrasno. Antioxidant activities of different polarity extracts from three organs of makrut lime (Citrus hystrix DC) and correlation with total flavonoid, phenolic, and carotenoid content Asian J Pharm Clin Res 2015;8(4):239-43.

25. Ak T, Gülçin I. Antioxidant and radical scavenging properties of curcumin. Chem Biol Interact 2008;174(1):27-37.

26. Pataki L, Zapp E. Basic Analytical Chemistry. ${ }^{\text {st }}$ ed. Oxford: Pergamon Press; 1980.

27. Aitken RJ, Buckingham D, Harkiss D. Use of a xanthine oxidase free radical generating system to investigate the cytotoxic effects of reactive oxygen species on human spermatozoa. J Reprod Fertil 1993;97(2):441-50.

28. Velioglu YS, Mazza G, Gao L, Oomah BD. Antioxidant activity and total phenolics in selected fruits, vegetables and grain products. J Agric Food Chem 1998;46(10):4113-7.

29. Simic A, Manojlovic D, Segan D, Todorovic M. Electrochemical behavior and antioxidant and prooxidant activity of natural phenolics. Molecules 2007;12(10):2327-40.

30. Happiot P, Pinson J, Yousfi N. Substituent effects on the redox properties of phenolates in acetonitrile: One electron redox potential. New J Chem 1992;16:877-81.

31. Kleinová M, Hewitt M, Brezová V, Madden JC, Cronin MT, Valko M. Antioxidant properties of carotenoids: QSAR prediction of their redox potentials. Gen Physiol Biophys 2007;26(2):97-103. 
32. Hodnick WF, Milosavljevic EB, Nelson JH, Pardini RS. Electrochemistry of flavonoids. Relationships between redox potentials, inhibition of mitochondrial respiration, and production of oxygen radicals by flavonoids. Biochem Pharmacol 1988;37(13):2607-11.

33. Crouch SR, Malmstadt HV. Mechanistic investigation of molybdenum blue method for determination of phosphate. Anal Chem 1967;39(10):1084-9.

34. Terpinc P, Abramovic H. A kinetic approach for evaluation of the antioxidant activity of selected phenolic acids. Food Chem
2010;121:366-71

35. Sroka Z, Cisowski W. Hydrogen peroxide scavenging, antioxidant and anti-radical activity of some phenolic acids. Food Chem Toxicol 2003;41(6):753-8

36. Amic D, Davidovic-Amic D, Beslo D, Rastija V, Lucic B, Trinajstic N SAR and QSAR of the antioxidant activity of flavonoids. Curr Med Chem 2007;14(7):827-45.

37. Beutner S, Bloedorn B, Hoffmann T, Martin HD. Synthetic singlet oxygen quenchers. Methods Enzymol 2000;319:226-41. 